\title{
Concentration Divided by Surface Area
}

National Cancer Institute

\section{Source}

National Cancer Institute. Concentration Divided by Surface Area. NCI Thesaurus. Code C102369.

The concentration divided by surface area. 